\title{
Research on the Impact of Timing Financing on M\&A Performance: The Intermediary Effect Based on Financing Efficiency
}

\author{
SHANG Qianqian ${ }^{1}$ \\ School of Economic, Shanghai University, China
}

\begin{abstract}
Timing financing theory holds that when listed companies are overvalued, they will increase equity financing. Different from previous studies, this study explores the mechanism of timing financing theory in China from the perspective of financing efficiency. Through the empirical study of $\mathrm{M} \& \mathrm{~A}$ cases of Listed Companies in China from 2007 to 2018, it is found that the timing financing behavior that increasing equity financing when overvalued reduces the positive impact of equity financing on $\mathrm{M} \& \mathrm{~A}$ performance. Further research found that the mediating effect of the financing efficiency exists, that is, the timing financing behavior does no increase listed companies' financing efficiency, so it can not help listed companies create value through $\mathrm{M} \& \mathrm{~A}$.
\end{abstract}

Keywords: Timing Financing Theory; equity financing; M\&A performance; financing efficiency

\section{Introduction}

$\mathrm{M} \& \mathrm{~A}$ is one of the most important investment methods of listed companies ( $\mathrm{Li}$, 2020)[1], whether financing can be obtained at a lower cost and whether sufficient funds can be obtained directly affect M \& A performance. At present, the mispricing of the stock market caused by inefficient capital market has attracted more and more attention from scholars. A large number of empirical evidences show that the window period when the stock price of listed companies deviates from the fundamentals has become one of the important considerations for companies to make investment and financing decisions. Stein's (1996) timing financing theory holds that companies can make use of window opportunities caused by market irrationality to arrange financing decisions rationally[2]. Shleifer \& Vishny (2003) extended the influence of timing financing theory from the perspective of $\mathrm{M} \& \mathrm{~A}[3]$. They believed that companies whose stock prices were overvalued would purchase assets by issuing shares or exchange shares to reducing financing costs and achieving limited arbitrage.

What kind of impact will the overestimation of M\&A companies bring to M\&A performance? Scholars have not reached a consistent conclusion on this question. Moreover, there are few researches on the influence mechanism of stock mispricing on M\&A performance( Luo \& Yang,2019)[4]. This paper explains the impact of stock

${ }^{1}$ Corresponding Author: SHANG Qianqian, School of Economic, Shanghai University, China; E-mail: shangqian@shu.edu.cn. 
mispricing on $\mathrm{M} \&$ A performance from the perspective of financing efficiency. Many studies in China have confirmed that equity financing can increase M \& A performance. However, the paper found that overestimation of listed companies will reduce the positive impact of equity financing on $\mathrm{M} \& \mathrm{~A}$ performance. This conclusion provides evidence for the timing theory of China's capital market, and enriches the research of equity financing on M\&A performance.

In terms of financing efficiency, the degree of marketization and property rights system in developed capital market is relatively sound, so there are few studies on financing efficiency( Shen, 2017; Yin et al., 2018)[5][6]. But due to the constraints of institutional environment, corporate governance level and financing in China's capital market, the financing efficiency is generally low (Zhang et al., 2017)[7]. Therefore, different from foreign research, this study explains the impact of corporate mispricing on M\&A performance from the perspective of financing efficiency. It is found that the reason for overestimation reduces the positive impact of equity financing on M\&A performance is that overestimation reduces financing efficiency, which in turn reduces M\&A performance. It means the mediating mechanism of financing efficiency on the influence of overvaluation on M\&A performance is established. The research on the impact of financing efficiency on timing financing is more in line with the background of China's capital market, and it also expands the mechanism research scope of the impact of mispricing on M\&A performance.

At present, the single financing method is the main problem of $\mathrm{M} \& \mathrm{~A}$ financing in China, mainly self-owned funds. In the future, with the formal implementation of the new securities law in China's capital market and the gradual relaxation of equity financing channels, the proportion of equity financing will increase, and the market timing behavior will be more extensive and common. Therefore, studying how to reasonably use capital market valuation deviations, reduce financing costs, improve financing efficiency, and achieve better M\&A performance is of great practical significance.

\section{Theoretical analysis and research hypothesis}

Since 1990s, the most important research direction of financing has been the impact of market mispricing on corporate financing decisions (Huang \& Ritter, 2005)[8]. According to behavioral corporate finance theory, inefficient market condition is an important factor in managers' financing decisions, that is, companies will choose financing strategies based on the degree of deviation between stock prices and fundamentals.

The first influential theory that the capital market affects corporate financing choices is Stein's (1996) timing financing theory. By constructing a rational capital budget analysis framework under the irrational capital market, Stein (1996) found that mispricing in the stock market will affect the companies' equity financing costs, so companies can choose financing methods based on market valuation deviations ${ }^{[2]}$. When the stock price is higher than fundamentals, companies will choose equity financing. Otherwise, companies will choose debt financing or repurchase shares. Then the market timing financing has been confirmed, Alti (2006), Hovakimian (2006) and Kayhan \& Titman (2007) all considered that companies have market timing behaviors when issuing securities[9][10][11]. Vagenas (2020) believes that companies with overvalued stock prices prefer to use share-based payments, and ultimately achieve the 
goal of arbitrage from high-valued stocks[12].

Some scholars in China have found that market mispricing does play an important role in equity payment(Sun \& Wei,2021)[13]. Specific to China's capital market, although there are many financing options available, the financing methods that meet the company's financing needs are very limited. Companies generally have a funding gap in China. That's because companies have low efficiency in the allocation of credit funds, and there are many restrictions on equity financing. This study believes that although timing financing can help listed companies to alleviate the financing constraints, but due to the imperfect internal governance of most listed companies in China, such as the absence of major shareholders or the high ownership concentration, the management lacks strategic $M$ \& A motivation, and the timing financing often has a certain degree of blindness. Therefore, the study conjectures that the timing financing will cause companies to deviate from the optimal capital structure and reduce the financing efficiency of listed companies, so it will not help increase $\mathrm{M}$ \& $\mathrm{A}$ performance. So we assume that:

H1: Timing financing will not help listed companies increase M\&A performance.

H2: Timing financing affects M\&A performance through reducing financing efficiency.

\section{Research Design}

\subsection{Sample selection and data source}

The M\&A samples and their financial data come from CSMAR and Wind. There are 5,616 A-share M\&A samples in 2004-2018. Because the impact of M \& A lasts for 3 years, so only retain the case with the largest scale of $M$ \& A within 4 years; Considering that split share structure basically ended in 2006, so delete M \& A cases before 2006; Delete financial institutions; Delete debt restructuring, asset replacement and asset divestiture cases; Delete ST and * ST companies.

\subsection{Variable definition}

\subsubsection{Company mispricing}

In this study, we use the method of Rhodes-Kropf et al. (2005)[14] to decompose $M / B$ :

$$
\mathrm{M} / \mathrm{B}=(\mathrm{M} / \mathrm{V}) *(\mathrm{~V} / \mathrm{B})
$$

Taking the $\operatorname{logarithm}$ on both sides, let $\log M=m, \log V=v, \log B=b$, the equation is converted into:

$$
\mathrm{m}-\mathrm{b}=(\mathrm{m}-\mathrm{v})+(\mathrm{v}-\mathrm{b})
$$

$(\mathrm{m}-\mathrm{v})$ is the deviation between market value and intrinsic value, that is the company's valuation deviation; $(\mathrm{v}-\mathrm{b})$ is the deviation between intrinsic value and book value, that is the internal growth opportunity of the company. According to the literature, the deviation between market value and intrinsic value may come from the company level or the industry level. Equation (2) is transformed into: 


$$
\mathrm{m}_{\mathrm{i}, \mathrm{t}}-\mathrm{b}_{\mathrm{i}, \mathrm{t}}=\left[\mathrm{m}_{\mathrm{i}, \mathrm{t}}-\mathrm{v}\left(\theta_{\mathrm{i}, \mathrm{t}} ; \alpha_{\mathrm{j}, \mathrm{t}}\right)\right]+\left[\mathrm{v}\left(\theta_{\mathrm{i}, \mathrm{t}} ; \alpha_{\mathrm{j}, \mathrm{t}}\right)-\mathrm{v}\left(\theta_{\mathrm{i}, \mathrm{t}} ; \alpha_{\mathrm{j}}\right)\right]+\left[\mathrm{v}\left(\theta_{\mathrm{i}, \mathrm{t}} ; \alpha_{\mathrm{j}}\right)-\mathrm{b}_{\mathrm{i}, \mathrm{t}}\right](3)
$$

$v\left(\theta_{i, t} ; \alpha_{j, t}\right)$ represents the estimated value of the firm $\mathrm{i}$ in year $\mathrm{t}$ based on the estimation coefficient $\alpha_{j, t}$ of the industry $\mathrm{j}$ in year $\mathrm{t} ; v\left(\theta_{i, t} ; \alpha_{j}\right)$ represents the estimated long-term value of the firm based on the estimation coefficient $\alpha_{j}$ of the long industry $\mathrm{j}$.

Therefore, $\left[m_{i, t}-v\left(\theta_{i, t} ; \alpha_{j, t}\right)\right]$ represents the mispricing at company level; $\left[v\left(\theta_{i, t} ; \alpha_{j, t}\right)-v\left(\theta_{i, t} ; \alpha_{j}\right)\right]$ represents the mispricing at industry level; $\left[v\left(\theta_{i, t} ; \alpha_{j}\right)-\right.$ $b_{i, t}$ ] represents the firm 's growth opportunities.

This study selects the mispricing at company level, that is $\left[m_{i, t}-v\left(\theta_{i, t} ; \alpha_{j, t}\right)\right]$. So we need calculate the estimated value of the firm i in year $\mathrm{t} v\left(\theta_{i, t} ; \alpha_{j, t}\right)$, regress the following equation by year and industry:

$\mathrm{m}_{\mathrm{it}}=\alpha_{0 \mathrm{jt}}+\beta_{1 \mathrm{jt}} \mathrm{b}_{\mathrm{it}}+\beta_{2 \mathrm{jt}} \ln (\mathrm{NI})_{\mathrm{it}}^{+}+\beta_{3 \mathrm{jt}} \mathrm{I}(<0) \ln (\mathrm{NI})_{\mathrm{it}}^{+}+\beta_{4 \mathrm{jt}} \mathrm{LEV}_{\mathrm{it}}+\beta_{5 \mathrm{jt}} \mathrm{LEV}_{\mathrm{it}}^{2}+\varepsilon_{\mathrm{it}}$

$\mathrm{m}_{i t}$ is the market value of firm $\mathrm{i}$ at the end of year $\mathrm{t}$, expressed by the logarithm of the sum of the equity market value and the bond market value; $b_{i t}$ is the logarithm of the total book assets of firm $\mathrm{i}$ at the end of year $\mathrm{t}$; $(N I)_{i t}^{+}$is the net profit after non-recurring profit and loss deduction where NI is positive only; I $(<0)$ is dummy variable, if $N I$ is negative, $I_{(<0)}$ is 1 ; otherwise, $I_{(<0)}$ is $0 . L E V_{i t}$ is the financial leverage of company $i$ in year $t$, which is ( total assets - shareholders ' equity ) / total assets.

Regress formula (4) by industry and year, then get the estimated value of company $\mathrm{i}$ in year $\mathrm{t}$ :

$$
\widehat{\mathrm{m}_{\mathrm{it}}}=\widehat{\alpha_{0 \mathrm{j}}}+\widehat{\beta_{1 \mathrm{jt}}} \mathrm{b}_{\mathrm{it}}+\widehat{\widehat{\beta_{2 \mathrm{jt}}}} \ln (\mathrm{NI})_{\mathrm{it}}^{+}+\widehat{\beta_{3 \mathrm{jt}}} \mathrm{I}\left(\langle 0) \ln (\mathrm{NI})_{\mathrm{it}}^{+}+\widehat{\beta_{4 \mathrm{jt}}} \mathrm{LEV}_{\mathrm{it}}+\widehat{\widehat{\beta_{5 \mathrm{t}}}} \mathrm{LEV}_{\mathrm{it}}^{2}\right.
$$

The estimated value estimated by formula 5 only includes company-specific factors, not industry valuation deviation, so the residual term $\varepsilon$ of the model is the valuation deviation caused by company factors $\left(\right.$ Misping $\left._{i t}\right)$ :

$$
\text { Misping }_{\mathrm{it}}=\mathrm{m}_{\mathrm{it}}-\widehat{\mathrm{m}_{\mathrm{it}}}
$$

\subsubsection{M\& A Performance}

This paper uses EVA (Economic Value Added) to measure M \& A Performance. Compared with the traditional financial indicator, it considers the capital cost, which can more measure whether an investment truly creates value for the enterprise (Zuo \& Lv, 2014; Zhao \& Li, 2017) accurately[15][16]. This paper chooses $E V A_{1}, E V A_{2}$, $E V A_{3}$ to represent the $\mathrm{M} \& \mathrm{~A}$ performance within three years after $\mathrm{M} \& \mathrm{~A}$.

Learn from the methods mentioned in Market Value Management Theory by Shi and Liu (2008)[17]:

$$
\mathrm{EVA}=[\mathrm{ROIC}-\mathrm{WACC}] * \mathrm{IC}
$$

ROIC means Return on Invested Capital; WACC means Weighted Average Cost of Capital; IC means Investment Cost. Both ROIC and IC can be obtained directly in the financial statements. WACC can be obtained through Formula (8). 


$$
\mathrm{WACC}=\mathrm{K}_{\mathrm{D}} *(1-\mathrm{T}) * \mathrm{D} /(\mathrm{D}+\mathrm{E})+\mathrm{K}_{\mathrm{E}} * \mathrm{E} /(\mathrm{D}+\mathrm{E})
$$

$\mathrm{K}_{\mathrm{D}}$ means debt interest rate, this paper uses the 3-5 year bank loan interest rate; $\mathrm{T}$ is the income tax rate at the end of each year; $\mathrm{K}_{\mathrm{E}}$ means the cost of equity that uses CAPM(Formula (9)) to measure.

$$
\mathrm{K}_{\mathrm{E}}=\mathrm{R}_{\mathrm{f}}+\beta\left(\mathrm{R}_{\mathrm{m}}-\mathrm{R}_{\mathrm{f}}\right)
$$

$\mathrm{R}_{\mathrm{f}}$ means risk-free rate, this paper uses one year bank deposit interest rate in the year of M\&A. Bmeans risk coefficient, $R_{m}$ means market return rate, that Shanghai Composite Index at the end of each year in this paper.

\subsubsection{Financing Efficiency}

Based on the research of financing efficiency factors by Wang et al. (2016)[18], this study selects DEA-Malmquist index to calculate the intertemporal financing efficiency change. The financing efficiency in the year of $\mathrm{M} \& \mathrm{~A}$ is defined as the dummy variable Fiance0. Take 1 for the total factor production change (Tfpch) is greater than 1 in the year of $\mathrm{M} \& \mathrm{~A}$, it indicates that the financing efficiency has increased compared with the year before M\&A, otherwise 0 .

\subsubsection{Control Variables}

The study also controls other related variables such as YAER and INDUSTRY. The definitions and explanations of all variables are as follows:

\begin{tabular}{|c|c|c|}
\hline Type & Name & Operational Definition \\
\hline $\begin{array}{l}\text { Dependent } \\
\text { Variables }\end{array}$ & $\begin{array}{c}\text { M \& A } \\
\text { Performance }\end{array}$ & $\begin{array}{l}E v a 1_{i}, E v a 2_{i}, E v a 3_{i} \text { mean in the first, second and third years after } \\
\text { M\&A respectively, take logarithm; }\end{array}$ \\
\hline $\begin{array}{l}\text { Independent } \\
\text { Variables }\end{array}$ & Mispricing & $\begin{array}{l}\text { Define continuous variable to measure the extent of mispricing: } \\
\text { Conmisp }=\mathrm{m}_{i t}-\widehat{m_{l t}}\left(\mathrm{~m}_{i t}-\widehat{m_{l t}} \text {, See formula } 6 \text { for details); Define }\right. \\
\text { dummy variable Highmisp, take } 1 \text { for } \mathrm{m}_{i t}-\widehat{m_{l t}}>0 \text {, otherwise } 0 \text {; Take } \\
\text { data from the year before } \mathrm{M} \& \mathrm{~A} \text {; }\end{array}$ \\
\hline $\begin{array}{l}\text { Mediating } \\
\text { Variables }\end{array}$ & $\begin{array}{l}\text { Financing } \\
\text { Efficiency }\end{array}$ & $\begin{array}{l}\text { Selects DEA-Malmquist index to calculate the intertemporal efficiency } \\
\text { change of } \mathrm{M} \& \mathrm{~A} \text { company's financing. Take } 1 \text { for the total factor } \\
\text { production change (Tfpch) is greater than } 1 \text { in the year of } M \& A \text {, } \\
\text { otherwise } 0 \text {. }\end{array}$ \\
\hline \multirow{6}{*}{$\begin{array}{l}\text { Control } \\
\text { Variables }\end{array}$} & $\begin{array}{l}\text { Equity } \\
\text { Financing }\end{array}$ & Take 1 for equity financing, otherwise 0 ; \\
\hline & Property & Take 1 for state-owned enterprises in the year before $M \& A$, otherwise 0 ; \\
\hline & $\begin{array}{l}\text { Listing } \\
\text { Board }\end{array}$ & Take 1 for listing on the main board, otherwise 0 ; \\
\hline & Profit & Average main business profit margin in three Years before $M \& A$; \\
\hline & $\begin{array}{l}\text { Capital } \\
\text { Structure }\end{array}$ & Average asset-liability ratio in three Years before M \& A; \\
\hline & $\begin{array}{l}\text { Operating } \\
\text { Capacity }\end{array}$ & Average total asset turnover rate in three Years before M \& A; \\
\hline
\end{tabular}

Table 1. Description of main variables 


\begin{tabular}{cl}
$\begin{array}{c}\text { Company } \\
\text { Growth } \\
\text { Corporate } \\
\text { Governance } \\
\text { Acquisition } \\
\text { Size }\end{array}$ & $\begin{array}{l}\text { Average revenue growth rate in three Years before M \& A; } \\
\text { members in the year before M \& A }\end{array}$ \\
Rela & Ratio of M \& A Value to Market Value at the end of the year before M \& A; \\
\hline
\end{tabular}

\subsection{Model construction}

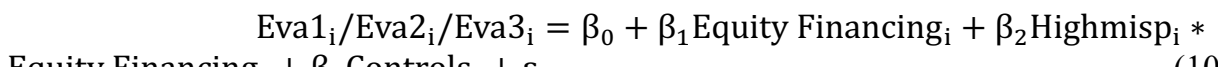
Equity Financing $i$

$$
\text { Eva }_{i}=\beta_{0}+\beta_{1} \text { Highmisp }_{i}+\beta_{2} \text { Financing Efficiency }_{\mathrm{i}}+\beta_{3} \text { Controls }_{\mathrm{i}}+\varepsilon_{\mathrm{it}}
$$

For H1, we choose OLS model to regress the formula (10).

For $\mathrm{H} 2$, we select $E v a 1_{\mathrm{i}}$ as the dependent variable and select formula (10) and (11) to test the intermediary mechanism of financing efficiency. We refer to the method of Wen and Ye (2014) to test the mediating effect, the mediating effect of M\&A financing efficiency is shown in Figure 1[19].

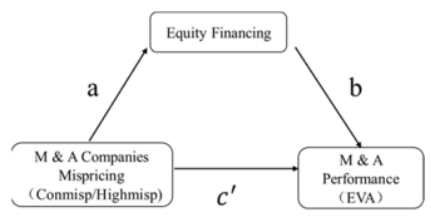

Figure 1. Test of the mediating effect of M\&A Financing Efficiency

Path a indicates the impact of the independent variable on the mediating variable; path $b$ indicates the impact of the mediating variable on the dependent variable; path $\mathrm{c}^{\prime}$ indicates the impact of the independent variable on the dependent variable when consider the mediating variable. If both path $\mathrm{a}$ and path $\mathrm{b}$ are significant, the mediation effect is significant. If at least one of path $a$ and path $b$ is not significant, use the Bootstrap method to check whether the product of the coefficients is significant.

\section{Empirical results and analysis}

\subsection{Descriptive statistics analysis}

The results of descriptive statistics are reported in Table 2. Through descriptive statistics, it is found that EVA after $\mathrm{M} \& \mathrm{~A}$ is increasing year by year, which shows that M \& A in China has created value for companies. Highmisp, which is dummy variable that represents the company level mispricing, it's mean is 0.79 , which shows that listed companies in China are overvalued. The median of financing efficiency was 0 , indicating that more than half of the listed companies' financing efficiency decrease in the year of M\&A. 
Table 2. Descriptive statistics

\begin{tabular}{lcccccc}
\hline Variables & $\mathbf{N}$ & mean & sd & min & p50 & max \\
\hline Eva1 & 1948 & 23.81 & 1.350 & 17.90 & 23.76 & 29.87 \\
Eva2 & 1588 & 23.87 & 1.460 & 14.76 & 23.86 & 30.24 \\
Eva3 & 1225 & 23.93 & 1.470 & 18.21 & 23.86 & 30.21 \\
Highmisp & 2097 & 0.790 & 0.410 & 0 & 1 & 1 \\
Conmisp & 2097 & 0.170 & 4.290 & -18.95 & 1.070 & 3.180 \\
Equity Financing & 2124 & 0.400 & 0.490 & 0 & 0 & 1 \\
Financing Efficiency & 935 & 0.420 & 0.490 & 0 & 0 & 1 \\
Property & 2107 & 0.300 & 0.460 & 0 & 0 & 1 \\
Profit & 2097 & 10.84 & 10.96 & -11.41 & 9.020 & 41.71 \\
Capital Structure & 2097 & 41.02 & 21.43 & 1.390 & 39.66 & 460.7 \\
Operating Capacity & 2097 & 0.750 & 0.530 & 0.0200 & 0.630 & 7.290 \\
Corporate Governance & 2092 & 0.370 & 0.0500 & 0 & 0.330 & 0.710 \\
Acquisition Size & 1924 & 0.210 & 0.350 & 0 & 0.0700 & 1.690 \\
Rela & 2016 & 0.440 & 0.500 & 0 & 0 & 1 \\
\hline & & & & & &
\end{tabular}

\subsection{Empirical result analysis}

\subsubsection{Equity financing, mispricing and $M \&$ A performance}

Table 3 reports the moderating effect of the company's mispricing on the impact of equity financing on $\mathrm{M} \& \mathrm{~A}$ performance, the regression results in Table 3 show that the coefficient of equity financing on the performance within three years after M\&A are significantly positive, and equity financing helps increase M\&A performance. The result is the same as the conclusions of Chen et al. (2020) that equity financing significantly increases the company's M\&A performance[20].

However, after adding the cross multiplication term of overestimation and equity financing, it is found that the cross multiplication term coefficient is significantly negative, indicating that using equity financing when overestimated will reduce the positive impact of equity financing on M \& A performance. It may be because when the company is overvalued, the company's managers will cater to the market for financing in order to maintain or increase the stock price, and raise more cheap capital, including equity financing(Jensen, 2005)[21], even if the company has sufficient internal funds(Polk \& Sapienza, 2009)[22]. The internal governance structure of most listed companies in China is not perfect. For example, the state-controlled enterprises generally have the problems of the absence of major shareholders or high equity concentration, and the management lacks the initiative power of strategic $\mathrm{M} \& \mathrm{~A}$. Therefore, when the listed company is overestimated, it will conduct inefficient M\&A financing out of catering to market motives, which can not help increase $\mathrm{M} \& \mathrm{~A}$ performance. 
Table 3 The moderating effect of corporate mispricing on the impact of equity financing methods on M\&A performance

\begin{tabular}{|c|c|c|c|}
\hline Variables & $\begin{array}{c}\text { (1) } \\
\text { Eva1 }\end{array}$ & $\begin{array}{c}\text { (2) } \\
\text { Eva2 }\end{array}$ & $\begin{array}{c}\text { (3) } \\
\text { Eva3 }\end{array}$ \\
\hline Equity Financing & $\begin{array}{c}0.460 * * * \\
(3.68)\end{array}$ & $\begin{array}{c}0.460 * * * \\
(3.23)\end{array}$ & $\begin{array}{c}0.497 * * * \\
(3.08)\end{array}$ \\
\hline $\begin{array}{l}\text { Highmisp*Equity } \\
\text { Financing }\end{array}$ & $\begin{array}{c}-0.317 * * * \\
(-2.66)\end{array}$ & $\begin{array}{c}-0.376 * * * \\
(-2.77)\end{array}$ & $\begin{array}{c}-0.440 * * * \\
(-2.88)\end{array}$ \\
\hline Property & $\begin{array}{c}0.438 * * * \\
(6.29)\end{array}$ & $\begin{array}{c}0.461 * * * \\
(5.69)\end{array}$ & $\begin{array}{c}0.449 * * * \\
(4.89)\end{array}$ \\
\hline Profit & $\begin{array}{c}0.034 * * * \\
(10.91)\end{array}$ & $\begin{array}{c}0.040 * * * \\
(11.01)\end{array}$ & $\begin{array}{c}0.038^{* * * *} \\
(9.08)\end{array}$ \\
\hline Capital Structure & $\begin{array}{c}0.019 * * * \\
(12.09)\end{array}$ & $\begin{array}{c}0.017 * * * \\
(9.41)\end{array}$ & $\begin{array}{c}0.015^{* * *} \\
(7.65)\end{array}$ \\
\hline Operating Capacity & $\begin{array}{c}0.310 * * * \\
(4.85)\end{array}$ & $\begin{array}{c}0.330 * * * \\
(4.46)\end{array}$ & $\begin{array}{c}0.403 * * * \\
(4.82)\end{array}$ \\
\hline Corporate Governance & $\begin{array}{l}-0.561 \\
(-1.02)\end{array}$ & $\begin{array}{c}-1.346^{* *} \\
(-2.09)\end{array}$ & $\begin{array}{l}-0.975 \\
(-1.25)\end{array}$ \\
\hline Acquisition Size & $\begin{array}{c}0.696 * * * \\
(7.07)\end{array}$ & $\begin{array}{c}0.836^{* * *} \\
(7.57)\end{array}$ & $\begin{array}{c}0.615^{* * *} \\
(5.09)\end{array}$ \\
\hline Rela & $\begin{array}{c}0.143^{* *} \\
(2.16)\end{array}$ & $\begin{array}{c}0.174 * * \\
(2.21)\end{array}$ & $\begin{array}{l}0.136 \\
(1.46)\end{array}$ \\
\hline Constant & $\begin{array}{c}21.703 * * * \\
(49.88)\end{array}$ & $\begin{array}{c}22.557 * * * \\
(47.10)\end{array}$ & $\begin{array}{c}22.759 * * * \\
(41.30)\end{array}$ \\
\hline Obs & 1,702 & 1,378 & 1,051 \\
\hline R-squared & 0.255 & 0.263 & 0.248 \\
\hline Ind & Yes & Yes & Yes \\
\hline Year & Yes & Yes & Yes \\
\hline
\end{tabular}

Note: $*, * *, * *$, denote significant at the levels of $10 \%, 5 \%$ and $1 \%$ respectively; $\mathrm{T}$ value is in parentheses; the same below.

\subsubsection{M\&A company mispricing, financing efficiency and $M \& A$ performance}

The above research found that using equity financing when overestimated reduces the positive impact of equity financing on M\&A performance. The following explores the intermediary mechanism of timing financing on $M \&$ A performance from the perspective of financing efficiency. The regression results in Table 4 show that for path a, when $M$ \& A company is overestimated, the financing efficiency decreases. For path $\mathrm{b}$, the reduction of merger financing efficiency will reduce the $\mathrm{M} \& \mathrm{~A}$ performance, so the overestimation of $M \& A$ company will reduce $M \& A$ performance. For path $\mathrm{c}^{\prime}$, the overestimation of M\&A companies reduces $M \&$ A performance. This conclusion supports the research conclusion of Polk and Sapienza (2009) that catering to the market in the long run when overestimated can not help increase value. We find path a and path $b$ are both significant, so the mediating effect of financing efficiency is significant. Therefore, the intermediary effect of financing efficiency exists, that is, the overestimation of $\mathrm{M} \& \mathrm{~A}$ companies affects $\mathrm{M} \& \mathrm{~A}$ performance through financing efficiency. 
Table 4 Test of the mediating effect of M\&A Financing Efficiency

\begin{tabular}{|c|c|c|}
\hline \multirow{2}{*}{ Variables } & (1) & (2) \\
\hline & Fiance0 & Eva1 \\
\hline Highmisp & $\begin{array}{c}-1.003 * * * \\
(-3.971)\end{array}$ & $\begin{array}{c}-0.927 * * * \\
(-6.167)\end{array}$ \\
\hline Fiance0 & & $\begin{array}{c}0.269 * * * \\
(3.240)\end{array}$ \\
\hline Property & $\begin{array}{c}-0.031 \\
(-0.174)\end{array}$ & $\begin{array}{c}0.294 * * * \\
(3.302)\end{array}$ \\
\hline Profit & $\begin{array}{c}0.008 \\
(0.724)\end{array}$ & $\begin{array}{c}0.057 * * * \\
(8.750)\end{array}$ \\
\hline Capital Structure & $\begin{array}{c}0.030 * * * \\
(5.080)\end{array}$ & $\begin{array}{c}0.025^{* * *} \\
(8.218)\end{array}$ \\
\hline Operating Capacity & $\begin{array}{c}-0.301 \\
(-1.599)\end{array}$ & $\begin{array}{c}0.430 * * * \\
(5.076)\end{array}$ \\
\hline Corporate Governance & $\begin{array}{c}0.543 \\
(0.394)\end{array}$ & $\begin{array}{c}0.409 \\
(0.477)\end{array}$ \\
\hline Acquisition Size & $\begin{array}{l}0.406^{*} \\
(1.918)\end{array}$ & $\begin{array}{c}0.702 * * * \\
(6.078)\end{array}$ \\
\hline Rela & $\begin{array}{c}0.053 \\
(0.321)\end{array}$ & $\begin{array}{c}0.126 \\
(1.458)\end{array}$ \\
\hline Constant & $\begin{array}{c}0.944 \\
(0.753)\end{array}$ & $\begin{array}{c}21.344 * * * \\
(25.536)\end{array}$ \\
\hline Obs & 859 & 857 \\
\hline R-squared & & 0.336 \\
\hline Ind & Yes & Yes \\
\hline Year & Yes & Yes \\
\hline
\end{tabular}

\section{Research Conclusions and Policy Implications}

This study explains the impact mechanism of timing financing on $M \&$ A performance. It finds that increasing equity financing when overvalued reduces the positive impact of equity financing on $\mathrm{M} \& \mathrm{~A}$ performance. Further research found that the mediating effect of the financing efficiency exists, that is, timing financing of listed companies reduces their financing efficiency, which can not help listed companies create value through $\mathrm{M} \& \mathrm{~A}^{1}$.

Chinese companies face the dilemma of single financing channel at present. Therefore, it is necessary for listed companies to identify the mechanism of capital market mispricing affecting $\mathrm{M} \& \mathrm{~A}$ performance, give full play to the favorable motivation of market value management, resist the unfavorable motivation of catering

\footnotetext{
${ }^{1}$ In order to ensure the robustness of the empirical results, we replaced the mispricing proxy variable with a continuous variable, it means defining Conmisp $=\mathrm{m}_{i t}-\widehat{m_{l t}}$ as the mispricing proxy variable.Then regress the modle again, the research results are robust. Due to space limitations, it is no longer listed here.
} 
to the market, and realize the synergistic growth of market value and intrinsic value through the combination of $\mathrm{M} \& \mathrm{~A}$ and financing. Listed companies should also strengthen the concept of industry-finance integration and realize positive interaction between physical operation and capital operation of listed companies. M \& A and financing using market timing should be based on company's overall value growth, and eliminate the high premium acquisition that can not create value.

\section{Reference}

[1] Li SM, Huang ZH, Guo JJ. Capital Market Pricing and Corporate Acquisions: Evidence from Chinese A-share Firms. Economic Research Journal. 2020July; 55(7): 41-57.

[2] Stein JC. Rational Capital Budgeting in an Irrational World. Journal of Business.1996April; 69(4): 429-455.

[3] Shleifer A, Vishny RW. Stock Market Driven Acquisitions. Journal of Financial Economics. 2003March; 70(3): 295-311.

[4] Luo Q, Yang WY. Stock Mispricing and M\&A : A Literature Review. Journal of Beijing Technology and Business University(Social Sciences), 2019May; 34(05):81-91.

[5] Shen D. Research on Financing Efficiency of SMEs in NEEQ Market: Private Placement Based on Three Stage DEA Model. Audit \& Economy Research. 2017March; 32(3): 78-86.

[6] Ying XJ, Liu XH, Li C. Analyze Financing Efficiency of Small and Micro Enterprises in Shandong Province_-Base on DEA Model and Malmquist index. Journal of Qingdao University (Natural Science Edition) .2018April; 31(4): 147-151.

[7] Zhang HJ. Internal Control, Legal Environments and Corporate Financing Efficiency__Evidence from A-Share Listed Companies in China. Journal of Shanxi Finance and Economics University.2017July; 39(7): 84-97.

[8] Huang R, Ritter JR. Testing the Market Timing Theory of Capital Structure. Kennesaw State: Kennesaw State University. Working paper. 2005.

[9] Alti A. How Persistent Is the Impact of Market Timing on Capital Structure?. The Journal of Finance. 2006April; 61(4): 1681-1710.

[10] Hovakimian A. Are observed capital structures determined by equity market timing?. Journal of Finance and Quantitative Analysis. 2006January; 41(1): 221-243.

[11] Kayhan A, Titman S. Firms' histories and their capital structures. Journal of Financial Economics. 2007January;83 (1):1-32.

[12] Vagenas NE.The Benefits of Overvaluation: Evidence from Mergers and Asquisitions. Financial Management. 2020January; 49(1),91-133.

[13] Sun Y, Wei BY. Impact of Mispricing on the Consideration of Stock Payment: A Modified Model Based on Price-to-Book Ratio Decomposition. Research on Financial and Economic Issues. 2021March; (03):68-74.

[14] Rhodes-Kropf M, Viswanathan S, Robinson DT. Valuation Waves and Merger Activity: The Empirical Evidence. Journal of financial Economics.2005January; 77(1): 561-603.

[15] Zuo XH, Lv JY. Research of Listed Companies' M\&A Performance Based on EVA. The Theory and Practice of Finance and Economics. 2014June; 35(6): 34-39.

[16] Zhao X, Li X, The Research of M\&A Performance of Chinese Real Estate Industry Listed Companies. Jilin Normal University Journal(Humanities \& Social Science Edition). 2017May; 45(5): 94-103.

[17] Shi GY, Liu GF. Theory on Market Value Management. Peking University Press.2008.

[18] Wang XN, Du L, Wang QT. Analysis on financing efficiency of small and medium sized enterprises based on three stage DEA model. Statistics and Decision. 2016May; (5): 179-182.

[19] Chen JQ, Zhao X, Niu XT. A Study on the Impact of Payment Methods M\&A Performance from the Perspective of Financing Constrains.Macroeconomics.2020April; (4):16-27.

[20] Wen ZL,Ye BJ. Analyses of Mediating Effects: The Development of Methods and Models. Advances in Psychological Science. 2014May; 22(5): 731-745.

[21] Jensen MC. Agency costs of overvalued equity. Financial Management. 2005January; 34(1): 5-19.

[22] Polk C, Sapienza P. The Stock Market and Corporate Investment: A Test of Catering Theory. Reriew of Financial Studies. 2009January; 22(1): 187-217. 